16 a 18 de outubro de 2019 - Campinas | Brasil

\title{
Economia política da cidade em Jundiaí (SP): planejamento local para atração e viabilização do espaço para as empresas.
}

\author{
João Eduardo Souza Oliveira*, Prof. Dr. Márcio Cataia.
}

\begin{abstract}
Resumo
O presente trabalho busca analisar o desenvolvimento da política local de atração de empresas em Jundiaí (SP). Esse município possui uma situação geográfica, especialmente para as empresas que têm na logística de transporte um fundamento destacado, privilegiada, pois esta é atravessada por vias expressas, proporcionando assim grande fluidez territorial. Essa situação é realçada pelos nos Planos de Atração das empresas e no sítio da Prefeitura de Jundiaí como "estratégica", ou como afirma o Guia do Investidor, "O melhor endereço do Brasil". Conjuntamente a essa dada situação geográfica, o município desenvolve outras ações para atração de novas empresas, como robustos investimentos nas áreas de Urbanismo, Saneamento, Habitação e Trabalho. Funções que envolvem majoritariamente serviços e equipamentos de transporte.
\end{abstract}

\section{Palavras-chave:}

Poder local, Uso do Território, Guerra dos Lugares.

\section{Introdução}

A cidade de Jundiaí é atravessada por importantes rodovias, dentre elas: Anhanguera e Bandeirantes, que autorizam o acesso rápido aos aeroportos internacionais de Cumbica (Guarulhos) e Viracopos (Campinas). Também possui a Ferrovia Santos-Jundiaí, que faz a ligação com o principal porto do Brasil, o Porto de Santos. Ela ainda possui o aeroporto executivo Comandante Rolim Adolfo Amaro, a Rodovia D. Gabriel Paulino Bueno Couto que conecta a região de Sorocaba e a Rodovia João Cereser que liga à Microrregião Bragantina. Deve ser destacado o fato do município possuir uma Estação Aduaneira do Interior ou "porto seco", o que, em tese, permite a aceleração e desembaraço de exportações e importações, considerando assim, especialmente, o grande número de empresas transnacionais presentes.

Contando com mais de 500 empresas cadastradas na Prefeitura, a cidade voltou seu Planejamento Estratégico, confeccionado pelo Departamento de Planejamento, Programas e Ações Estratégicas, para a inserção da cidade aos ditames mais modernizantes da globalização.

\section{Resultados e Discussão}

A pesquisa se desenvolve por meio do estudo e análise dos Planos Municipais de atração de empresas nas três últimas gestões municipais, cotejando-os com as efetivas instalações de empresas. Para a análise da efetividade dessas políticas locais, foram levantados dados da base RAIS/CAGED, para reconhecer os principais setores econômicos e suas dinâmicas em Jundiaí, sendo a de indústria de transformação aquela que possui maior relevância e que no período de 2010 à 2014 teve um crescimento acima da linha de tendência dos anos anteriores. Com base nos dados da Finbra e Siconfi, foi possível observar um crescimento dos investimentos municipais em infraestrutura urbana durante esse mesmo período, o que poderia mostrar um reflexo positivo das políticas locais na atração de empresas. Todavia, esses mesmos dados revelam que apesar da manutenção relativamente alta desses investimentos municipais, que atingem seu ápice em 2016, após a implementação do Plano Desenvolve Jundiaí, este não possui correlação com a dinâmica das empresas do setor da indústria de transformação. Ao contrário, vê-se um decrescimento do número de estabelecimentos a partir do ano de 2015, o que coloca em cheque a capacidade de efetivação das políticas locais de atração frente ao poder das grandes empresas globais.

Por princípio, a atração de empresas, por meio de políticas públicas, explicitariam um processo de viabilização do espaço para as grandes empresas (SILVEIRA, 2003), que faria crescer a economia local. Esse discurso e ações dos governos locais se reforçam e se amplia no período atual da globalização, em que a guerra dos lugares (SANTOS, 2012) se acirra e se torna um ditame da política das empresas (SANTOS, 1998). Dessa forma, entendemos que Jundiaí é um "laboratório" das políticas de inserção dos lugares ao mundo da globalização.

\section{Conclusão}

Percebemos ao longo da pesquisa, o desenvolvimento de um conjunto de políticas locais para atração de empresas. No entanto, apesar de ao longo das últimas duas gestões terem sindo implementados planos que mostraram certos resultados na viabilização do espaço, com a instalação de infraestruturas de transporte, assim como efetiva atração de novas indústrias e empresas, observa-se que nos últimos anos esses mesmos resultados não tenham sido alcançados. Isso coloca em questão o poder de determinação das politicas locais frente as politicas das empresas na globalização.

\section{Agradecimentos}

Gostaria de deixar meu imenso agradecimento ao meu orientador e professor Márcio Cataia, ao seu orientando Luciano, ao SAE pelo fomento tornando possível esta pesquisa, ao grupo de estudos, a minha família e colegas.

SANTOS, M. Da política do Estado à política das empresas. Cadernos da Escola do Legislativo de Minas Gerais, n. 6, p. 9-23, dez. 1998.

SANTOS, M. Por uma outra globalização: do pensamento único à consciência universal. Rio de Janeiro: Editora Record, 2012.

SILVEIRA, M. L. Região e a invenção da viabilidade do território. In: SOUZA, M. A. A. (Org.). Território brasileiro: usos e abusos. Campinas: Edições Territorial, 2003. 